\title{
PENGARUH KUALITAS INFORMASI BERBASIS CYBER TERHADAP KAPABILITAS PETANI SAYURAN MENGELOLA INOVASI DI JAWA BARAT
}

\author{
Darojat Prawiranegara ${ }^{1}$, Sumardjo ${ }^{2}$, Djuara P. Lubis ${ }^{2}$ dan Sri Harijati ${ }^{2}$ \\ ${ }^{1}$ Mahasiswa Mayor Ilmu Penyuluhan Pembangunan Sekolah Pascasarjana IPB \\ ${ }^{2}$ Dosen Pascasarjana Institut Pertanian Bogor \\ E-mail: darojatjajat@yahoo.com
}

\begin{abstract}
ABSTRAK. Keterbukaan informasi global dalam dunia internetworking dapat berperan dalam membantu petani memilih informasi yang sesuai dengan situasi dan kondisi di lapangan. Membaiknya sarana prasarana penunjang Teknologi Informasi Komunikasi (TIK), massifnya penggunaan TIK seperti handphone dan internet, masyarakat pedesaan kini lebih berkesempatan dalam memilih dan menilai informasi guna meningkatkan kapabilitas mengelola inovasinya. Penelitian ini bertujuan untuk memberikan gambaran persepsi petani terhadap kualitas informasi dan melihat pengaruhnya terhadap kapabilitas petani mengelola inovasi di Jawa Barat. Hasil penelitian yang dilakukan terhadap 243 petani menunjukan bahwa tingkat kapabilitas petani mengelola inovasi masih rendah dan persepsi terhadap kualitas informasi dinyatakan sedang. Karakteristik kualitas informasi relevan, kepahaman, akurasi, kehandalan, keaktualan, kelengkapan dan ketepatwaktuan, secara serempak berpengaruh terhadap kapabilitas petani mengelola inovasi.
\end{abstract}

Kata kunci: kualitas informasi, kapabilitas petani mengelola inovasi, persepsi

\section{EFFECT OF INFORMATION QUALITY BASED ON CYBER TOWARD VEGETABLE FARMERS CAPABILITY TO MANAGE INNOVATION IN WEST JAVA}

\begin{abstract}
Disclosure of information in the global internetworking world's can plays role in helping farmers to choose the information that is appropriate to the situation and conditions in the field. Improvement in supporting infrastructure of Information Communication Technology (ICT) and the massive use of ICTs such as mobile phones and internet give rural communities more opportunities in selecting and assessing the information in order to improve the behavior of innovation. This study aims to provide an overview of farmers' perceptions of the information quality and see the effects on farmers capability to manage innovation in West Java. Results of a study of 243 farmers showed that the rate of innovation capabilities of farmers is still weak and the perception of the quality of information is moderate. The quality characteristics of the relevant information, understanding, accuracy, reliability, contemporary, completeness and timeliness, simultaneously influence the farmers capability to manage innovation.
\end{abstract}

Key words: quality of information, farmers capability to manage innovation, perception

\section{PENDAHULUAN}

Petani dalam mengelola usaha taninya, menggunakan sumber-sumber pengetahuan dan informasi yang berbeda baik perorangan maupun yang bersumber dari lembaga swasta/pemerintah dengan perantaraan berbagai media. media yang biasa digunakan selama ini adalah televisi dan radio. Namun demikian, sarana informasi melalui media massa tersebut minim kontenkonten yang berhubungan dengan teknologi tepat guna yang dapat diterapkan oleh petani. Salah satu cara untuk mengakses informasi dan pengetahuan pertanian yang baik adalah dengan memanfaatkan internetworking. Internet dipilih karena dapat terhubung dengan berbagai sumber informasi yang lebih beragam dan dapat dipilah sendiri oleh petani.

Keterbukaan informasi global dalam dunia internet working dapat berperan dalam membantu petani dengan melibatkannya secara langsung dengan sejumlah besar kesempatan dan membantu petani untuk memilih informasi yang sesuai dengan situasi dan kondisi di lapangan. Perkembangan jaringan pertukaran informasi di antara pelaku yang terkait, merupakan aspek penting untuk mewujudkan sistem pengetahuan dan informasi pertanian. Dengan dukungan teknologi informasi dan peran aktif institusi bidang pertanian, upaya untuk mengembangkan jaringan informasi bidang pertanian sampai di tingkat petani diharapkan dapat diwujudkan.

Teknologi informasi dan komunikasi (information and communication technology/TIK) telah membangun sistem sosial ekonomi menjadi lebih sederhana, praktis, luas, cepat dan multitasting. Melalui multimedia, jejaring nirkabel, teknologi seluler, internet dan akses serba digital, setiap orang di dunia dapat terkoneksi, berkomunikasi, berkolaborasi dan berbisnis secara online atau melalui instant messenger dan jejaring sosial (seperti: facebook, friendster, linked, coprol, twitter, whatsapp dan sebagainya). Seiring dengan membaiknya sarana prasarana penunjang, meningkatnya upaya sosialisasi dan internalisasi TIK ke berbagai ruang, maka masyarakat pedesaan yang semula berakses lemah terhadap informasi dunia luar dan perkembangan ilmu pengetahuan dan teknologi, kini interaksinya menjadi semakin terbuka, terutama dengan massifnya penggunaan TIK, seperti handphone dan internet. Sosialisasi dan institusionalisasi TIK ke pedesaan kini menjadi program seluruh negara di dunia. 
Sekarang ini banyak petani yang sudah bisa mengakses internet bahkan sudah sangat akrab dengan internet. Banyak petani yang sudah mencari informasi tentang inovasi teknologi, teknik budidaya ataupun pemasaran melalui browsing di internet. Memperhatikan realitas tersebut sudah selayaknya kegiatan penyuluhan juga dapat mengakomodir hal ini. Perkembangan teknologi informasi sangat effektif untuk menyebarkan (diseminasi) teknologi, memperluas jejaring pemasaran maupun mengetahui fluktuasi harga suatu komoditas. Beberapa kebutuhan informasi utama petani yang paling penting bagi pertumbuhan dan perkembangan pertanian terkait pemanfaatan TIK adalah informasi pasar, informasi mengenai teknik dan teknologi terbaru, informasi mengenai program pembangunan pedesaan serta subsidi, tentang prakiraan cuaca, paket pelatihan terakhir (terbaru), berita pertanian umum, informasi asuransi/mengenai proses klaim asuransi, harga masuk dan ketersediaan produk pertanian, peringatan dini penanggulangan penyakit dan hama, pengujian tanah dan informasi contoh tanah (Vivek 2011).

Dalam bidang pertanian, Maureen (2009) menyatakan bahwa internet dapat dimanfaatkan dalam memperbaiki aksesibilitas petani terhadap informasi pasar, input produksi, tren konsumen, yang secara positif berdampak pada kualitas dan kuantitas produksi. Informasi pemasaran, praktek pengelolaan ternak dan tanaman yang baru, teknologi pengendalian penyakit dan hama tanaman/ternak, informasi peluang pasar dan harga pasar input maupun output pertanian merupakan sumber bagi petani untuk mengelola inovasi. Dengan demikian, kesuksesan petani dalam meningkatkan kapabilitas inovasinya sangat bergantung pada kualitas informasi yang didapat. Proses peningkatan kapabilitas petani melalui media internet merupakan suatu proses transformasi yang kompleks. Namun demikian, gambaran persepsi pengguna (petani) terhadap kualitas informasi yang ditampilkan dapat memberikan manfaat terhadap perbaikan pada isi (content) utamanya dan melihat pengaruhnya terhadap kapabilitas petani. Indikator karakteristik kualitas informasi merujuk pada indikator model DeLone dan McLean (1992) terdiri dari relevan, kepahaman, akurasi, kehandalan, keaktualan, kelengkapan dan ketepatwaktuan.

Pembahasan mengenai kapabilitas petani mengelola inovasi terkait erat dengan perilaku inovasi individu. Pengertian kapabilitas petani mengelola inovasi adalah semua perilaku individu yang diarahkan untuk menghasilkan, memperkenalkan, dan mengaplikasikan hal-hal 'baru', yang bermanfaat dalam berbagai level. Beberapa peneliti menyebutnya sebagai shop-floor innovation (DeJong and Kemp 2003). Indikator kapabilitas petani mengelola inovasi mengacu pada lima inti kapabilitas Baser and Morgan (2008) yang meliputi: (1) kemampuan beradaptasi dengan inovasi; (2) kemampuan menyaring inovasi; (3) kemampuan komitmen terhadap inovasi; (4) kemampuan melaksanakan inovasi; dan (5) kemampuan mengelola sumberdaya yang ada.

Penelitian ini bertujuan untuk mengukur: (1) sejauhmana persepsi petani terhadap kualitas informasi yang terdapat pada media internet; (2) sejauhmana kapabilitas petani mengelola inovasi di dataran tinggi Jawa Barat; dan (3) secara simultan, sejauhmana karakteristik informasi relevan, kepahaman, akurasi, kehandalan, keaktualan, kelengkapan dan ketepatwaktuan berpengaruh terhadap kapabilitas petani mengelola inovasi di Jawa Barat.

\section{METODE PENELITIAN}

Penelitian ini didesain secara kuantitatif dan kualitatif (Mixed method), dengan menggunakan metode survey eksplanatory. Penelitian dilakukan di dataran tinggi Jawa Barat berlokasi di Kabupaten Cianjur dan Kabupaten Bandung Barat. Penelitian dilaksanakan dari Bulan Juli 2013 sampai Oktober 2014. Petani sayuran yang dijadikan sampel penelitian berjumlah 243 orang (114 orang petani di Kabupaten Bandung Barat dan 129 orang petani di Kabupaten Cianjur). Pengumpulan data terhadap petani didasarkan atas pendapat atau persepsi petani terhadap indikator-indikator yang diajukan dalam mengukur peubah-peubah penelitian. Menurut Sarwono (2005), persepsi adalah proses kategorisasi terhadap rangsangan dari luar yang di dalamnya terdapat unsur pemberian arti dan penilaian (inferensiasi) terhadap obyek tersebut. Persepsi dapat diartikan sebagai proses pemberian makna yang di dalamnya terdapat proses seleksi/penilaian terhadap rangsangan berdasarkan pengamatan, wawasan, dan pengalamannya yang di dalamnya terdapat unsur penilaian terhadap peubah penelitian tersebut.

Variabel independen persepsi petani terhadap kualitas informasi (X) melalui TIK adalah pandangan petani terhadap ciri-ciri dari informasi yang bermutu, baik informasi yang diperoleh dari jaringan terkoneksi internet langsung maupun melalui keanggotaan lain. Indikator dari karakteristik kualitas informasi dalam penelitian ini meliputi: relevan, kepahaman, akurasi, kehandalan, keaktualan, kelengkapan dan ketepatwaktuan. Sedangkan variavel dependen $(\mathrm{Y})$ kapabilitas petani mengelola inovasi adalah perwujudan karakter dari perilaku individu yang ditampilkan dalam bentuk kemampuan menghadapi perubahan (inovasi) sesuai sumberdaya yang dimiliki. Indikator dari kapabilitas petani mengelola inovasi meliputi: kemampuan beradaptasi dengan inovasi; kemampuan menyaring inovasi; kemampuan komitmen terhadap inovasi; kemampuan mengelola sumberdaya yang ada; dan kemampuan menerapkan inovasi. Guna melihat pengaruh kualitas informasi terhadap kapabilitas petani mengelola inovasi, maka data dianalisis lebih lanjut menggunakan teknik analisis regresi. 
Setiap dimensi/aspek yang ditanyakan diuraikan terlebih dahulu, selanjutnya dilakukan penilaian terhadap kualitas masing-masing item akumulasi/keseluruhan dengan cara membuat tabel kategori penilaian. Perhitungan skor tiap-tiap komponen yang diteliti adalah dengan mengalikan seluruh frekuensi data dengan nilai bobotnya, selanjutnya dicari rentang skalanya (Umar 1999).

\section{HASIL DAN PEMBAHASAN}

\section{Persepsi Petani terhadap Karakteristik Kualitas Informasi}

Informasi memang sudah menjadi kebutuhan pokok bagi setiap manusia untuk dapat mengembangkan hidupnya baik secara politik, hukum, ekonomi, dan sosial budaya serta keamanan dalam rangka pengembangan pribadi dan lingkungannya. Oleh karena itu memperoleh informasi merupakan bagian dari Hak Asasi Manusia (HAM) sebagaimana ditegaskan dalam Pasal 28F Undang Undang Dasar Negara Republik Indonesia Tahun 1945 bahwa "Setiap orang berhak untuk berkomunikasi dan memperoleh informasi untuk mengembangkan pribadi dan lingkungan sosialnya, serta berhak untuk mencari, memperoleh, memiliki, menyimpan, mengolah, dan menyampaikan informasi dengan menggunakan segala jenis saluran yang tersedia“. UU No. 19 Tahun 2013. Mengamanatkan bahwa informasi sebagaimana dimaksud pada ayat (1) harus akurat, tepat waktu, dan dapat diakses dengan mudah dan cepat oleh petani, pelaku usaha, dan/atau masyarakat. Menurut O'Brien (2005); McLeod dan George (2007); Laudon dan Laudon (2007) informasi didefinisikan sebagai data yang telah diubah menjadi suatu konteks yang memiliki arti dan berguna untuk para pemakai akhir yang spesifik yang belum mereka ketahui sebelumnya. Jadi informasi adalah data yang diperoleh dan berguna bagi pemakai informasi setelah melalui proses persepsi pemberian arti terhadap karakteristik manfaat informasi dan berpengaruh terhadap keyakinan pengguna.

Dewasa ini pelaku pengembangan pertanian di Indonesia masih mengeluhkan minimnya informasi pasar dan informasi teknologi pertanian tepat guna yang dapat disediakan oleh pemerintah, dalam hal ini Kementerian Pertanian. Oleh karena itu, menjadi kewajiban kementerian untuk dapat menyediakan informasi pasar dan informasi teknologi pertanian bagi pelaku agribisnis. Salah satu sarana yang dapat digunakan untuk penyebaran informasi adalah internet atau situs web karena jangkauannya global, dan cepat diakses oleh pelaku pengembangan pertanian di daerah secara serentak. (Mulyandari dan Eko 2005).

Pengembangan sumber informasi pertanian nasional untuk informasi pasar dan informasi teknologi pertanian merupakan salah satu langkah untuk penguatan akses petani atau pelaksana pengembangan pertanian terhadap informasi pasar (termasuk di dalamnya informasi produksi, pasar distribusi, dan bahan baku), serta informasi teknologi pertanian. Oleh karena itu, penyediaan informasi pasar dan informasi teknologi pertanian yang memadai merupakan fasilitas penting bagi petani dalam proses pengambilan keputusan dalam melakukan aktivitas pengembangan pertanian.

Kualitas pengetahuan dan informasi pertanian yang tersedia dalam internet dapat berperan membantu petani untuk memilih informasi yang sesuai dengan situasi dan kondisi di lapangan. Dengan dukungan teknologi informasi dan peran aktif institusi bidang pertanian, upaya untuk menyediakan informasi bidang pertanian sampai di tingkat petani diharapkan dapat diwujudkan. Informasi yang berkualitas baik untuk teknologi budidaya maupun untuk pemasaran hasil komoditas sayuran sangat diperlukan untuk dapat mendorong pada kemampuan petani sayuran dalam mengelola inovasi secara keseluruhan dalam satu wilayah. Agar kemampuan petani dalam mengelola inovasi meningkat maka petani memerlukan pengetahuan dan informasi mengenai berbagai topik, seperti: (1) hasil penemuan penelitian terbaru dari berbagai disiplin; (2) pengelolaan usahatani dan teknologi produksi; (3) pengalaman petani lain; (4) situasi mutakhir dan perkembangan yang mungkin terjadi di pasaran input dan hasil-hasil produksi; dan (5) kebijakan pemerintah.

Kesuksesan petani dalam meningkatkan kapabilitas inovasinya sangat bergantung pada kualitas informasi yang didapat. Kita ketahui bahwa karakteristik informasi yang terkandung dalam informasi bersifat tacit dan explicit. Beberapa informasi terkadang tidak reliable, relevan, complete dan understandable yang sangat sulit diterjemahkan langsung oleh petani. Nonaka (1995) dalam Sangkala (2007) membedakan dengan jelas antara tacit dan explicit knowledge. Menurutnya, tacit knowledge bersifat implisit, fisikal, artifisial, subyektif, pengetahuan berupa pengalaman (knowledge of experience; body), pengetahuan yang simultan (simultaneous knowledge) dan pengetahuan analog (analog knowledge). Tacit knowledge diciptakan di sini (here) dan sekarang (now) di dalam sutau konteks yang spesifik.

Explicit knowledge bersifat obyektif, eksplisit, meta fisikal, rasional (knowledge of rationality), sekuensial (knowledge of sequential) dan teoretis (digital knowledge). explicit knowledge menyangkut peristiwa atau obyek di sini (there) dan kemudian (then) dan lebih berorientasi pada teori yang bebas dari konteks, yang menurut Bateson disebut aktivitas "digital". Terkait dengan keduanya, Sangkala (2007) menegaskan bahwa yang terpenting sharing harus memperhatikan pelaku, materi, metode dan sarana prasarana pendukung (misal, disain ruang percakapan). Bahkan, untuk transfer perlu memperhatikan cultur transfer dan melakukan ruangruang dialog. Selain itu, sharing juga dapat dilakukan 
melalui mentoring, tutorial, coaching, magang dan sebagainya. Terpenting, sharing harus memperhatikan jenis pengetahuan, apakah tacit atau explicit. Benar bahwa pengetahuan tacit dapat ditransfer melalui media elektronik atau jejaring, tetapi pihak yang melakukan sharing (pendidik) harus memiliki pengetahuan dan peta dari warga belajar (transfer mapping).

Dalam penelitian ini, persepsi petani terhadap karakteristik kualitas informasi yang dijadikan indikator penelitian meliputi relevansi, kepahaman, akurasi, kehandalan, keaktualan, kelengkapan dan ketepat waktuan. Indikator tersebut merupakan bagian dari indikator kualitas informasi dalam model DeLone dan McLean (1992). Terkait dengan teknologi informasi, Jogiyanto (2007) menguji kualitas informasi dari model DeLone dan McLean (1992) yang menyatakan bahwa ketujuh indikator tersebut berpengaruh terhadap kesusksesan sistem informasi. Dalam penelitian ini, persepsi petani terhadap kualitas informasi yang termuat dalam media internet tertuju pada empat informasi yaitu: (1) hasil penemuan penelitian pengelolaan budidaya usahatani sayuran dan teknologi produksi; (2) informasi harga input dan output hasil pertanian; (3) informasi peluang pemasaran produk-produk hasil pertanian; dan (4) kebijakan pemerintah bidang pertanian.

Hasil penelitian pada Gambar 1 terlihat bahwa secara keseluruhan dilihat dari ketujuh dimensi indikator kualitas, kualitas informasi yang berupa informasi pemasaran menduduki urutan pertama, disusul informasi harga, informasi hasil penelitian, dan informasi kebijakan pertanian. Secara parsial berdasarkan dimensi masingmasing indikator kualitas dapat dijelaskan bahwa tingkat relevansi informasi pertanian; informasi yang berupa hasil penelitian lebih relevan (60.1\%), informasi harga sangat mudah dipahami (68.0\%), Informasi kebijakan dinilai lebih akurat (61.0\%), informasi penelitian lebih handal (54.9\%), informasi hasil penelitian lebih keaktualan (58.8\%), informasi pemasaran lebih lengkap (70.4\%) dan informasi harga dinilai lebih tepat waktu (63.4\%).

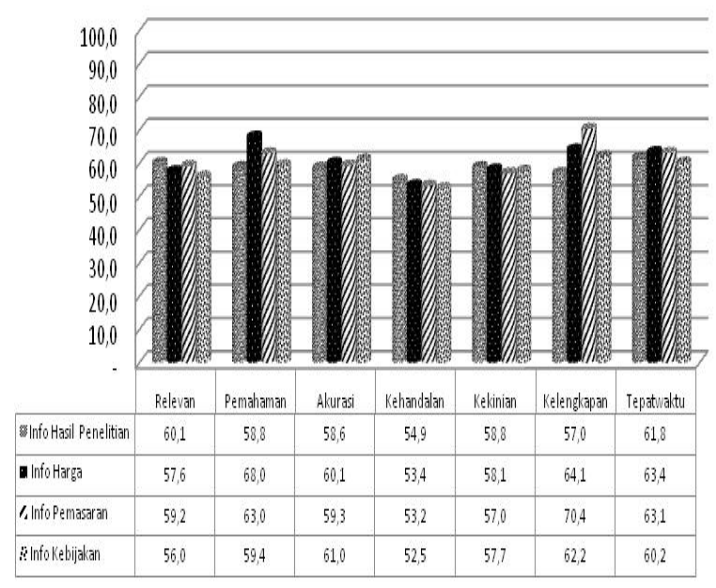

Gambar 1. Persentase penilaian petani terhadap kualitas informasi pertanian yang diakses pada media internet

Pada Tabel 1 terlihat bahwa indikator diperlukannya informasi yang berkualitas diukur dengan menggunakan tujuh dimensi yang dinyatakan dalam 28 butir pernyataan yang relevan. Jumlah skor tanggapan responden dalam tujuh dimensi pada variable karakteristik kualitas informasi diperoleh sebesar 4.061 dengan bobot skor tertinggi adalah 4 dan bobot terendah 1. Jika diklasifikasikan menjadi empat tingkatan maka rentang skor antar tingkatan dapat dihitung dengan cara menghitung nilai skor minimum: $1 \times 243 \times 7=1.701$, nilai skor maksimum: $4 \times 243 \times 7=6.804$. didapatkan range 6.804-1.701 $=5.103$, sehingga jenjang range 5.103:4 $=1.276$.

Dari hasil perhitungan Tabel 1, dibuat skala penilaian dengan kategori sangat rendah skor (1.7012.976), rendah (2.977-4.252), sedang (4.253-5.528) dan tinggi (5.529-6.804). Interval kategori untuk jumlah total skor tanggapan responden dalam tujuh dimensi variabel kualitas informasi pertanian dengan nilai 4.061. Berdasarkan interval kategori tersebut dapat disimpulkan bahwa tanggapan responden mengenai variabel kualitas informasi, secara umum termasuk dalam kategori rendah, hal tersebut menunjukkan bahwa informasi

Tabel 1. Jumlah dan persentase penilaian petani terhadap indikator kualitas informasi yang di akses pada media internet, Tahun 2015

\begin{tabular}{|c|c|c|c|c|c|c|c|c|c|c|c|}
\hline \multirow{3}{*}{ No. } & \multirow{3}{*}{$\begin{array}{l}\text { Indikator Kualitas } \\
\text { Informasi }\end{array}$} & \multicolumn{8}{|c|}{ Rekapitulasi Skor Jawaban Responden } & \multirow{2}{*}{\multicolumn{2}{|c|}{ Total }} \\
\hline & & \multicolumn{2}{|c|}{ Sangat rendah } & \multicolumn{2}{|c|}{ Rendah } & \multicolumn{2}{|c|}{ Sedang } & \multicolumn{2}{|c|}{ Tinggi } & & \\
\hline & & $\mathrm{n}$ & $\%$ & $\mathrm{n}$ & $\%$ & $\mathrm{n}$ & $\%$ & $\mathrm{n}$ & $\%$ & $\mathrm{~N}$ & $\%$ \\
\hline 1. & Relevan & 38 & 15,7 & 102 & 42,0 & 88 & 36,0 & 15 & 6,3 & 243 & 100,0 \\
\hline 2. & Kepahaman & 18 & 7,5 & 109 & 44,7 & 89 & 36,7 & 27 & 11,2 & 243 & 100,0 \\
\hline 3. & Keakurasian & 19 & 7,8 & 120 & 49,4 & 94 & 38,8 & 10 & 4,0 & 243 & 100,0 \\
\hline 4. & Kehandalan & 39 & 15,8 & 135 & 55,5 & 67 & 27,6 & 3 & 1,1 & 243 & 100,0 \\
\hline 5. & Keaktualan & 30 & 12,4 & 116 & 47,6 & 87 & 35,7 & 10 & 4,2 & 243 & 100,0 \\
\hline 6. & Kelengkapan & 18 & 7,5 & 101 & 41,5 & 99 & 40,8 & 25 & 10,2 & 243 & 100,0 \\
\hline \multirow[t]{3}{*}{7.} & Ketepatwaktuan & 12 & 4,8 & 114 & 47,0 & 105 & 43,0 & 13 & 5,1 & 243 & 100,0 \\
\hline & Akumulasi & 174 & & 796 & & 628 & & 102 & & 1.701 & \\
\hline & Jumlah skor & & 174 & & 1.592 & & 1.885 & & 410 & & 4.061 \\
\hline
\end{tabular}


yang berkualitas dengan karakteristik tertentu belum sepenuhnya digunakan dalam proses pengambilan keputusan usahatani. Informasi yang ditampilkan pada media internet belum seluruhnya berhubungan langsung dengan persoalan/kebutuhan petani. Beberapa petani menyatakan tidak menemukan jawaban atas persoalan mereka.

Dari tingkat pemahaman, petani masih merasa sulit memahami informasi terutama terkait dengan informasi hasil-hasil penelitian. Rata-rata petani tidak memiliki kemampuan mengungkapkan materi untuk kembali disampaikan pada petani lain, bahkan beberapa orang petani sulit memberikan interpretasi sehingga tidak mampu mengambil keputusan atas informasi (kebingunan informasi). Terungkap bahwa mereka lebih memahami informasi yang sifatnya praktis content seperti halnya informasi harga dan informasi pemasaran, mereka menginginkan informasi hasil penelitian seperti bagaimana pengelolaan budidaya tanaman yang disertai dengan gambar-gambar atau photo-photo yang menampilkan teknik budidaya tersebut. Mereka lebih menyukai situs-situs yang menampilkan hasil pengalaman usahatani karena ratarata situs tersebut disertai dengan gambar dan bahasa yang sederhana. Mereka saat ini, menganggap hanya informasi harga input atau output pemasaran yang mereka anggap mudah difahami. Informasi tersebut sangat mudah mereka sebarkan kepada petani lain karena mereka faham dan cukup jelas. Guna mengatasi masalah tersebut, beberapa petani yang dirasakan sulit difahami mengkomunikasikannya dengan pengurus dan beberapa lainnya berkomunikasi dengan para petugas pertanian yang ada di lapangan. Namun beberapa diantaranya, mereka mendiskusikannya di dalam keluarga. Hal ini dilakukan karena ada beberapa informasi yang sebenarnya masih bisa difahami setelah mendiskusikannya di dalam keluarga mereka.

Dilihat dari segi keakuratan dalam menjawab kebutuhan informasi, 41.6 persen petani mempercayai informasi yang berasal dari internet. Mereka beranggapan bahwa informasi yang ditampilkan sudah barang tentu informasi yang bisa dipercaya, karena dilihat oleh umum dan banyak koreksi jika terdapat kesalahan, sedangkan sebanyak 49.0 persen mengatakan ragu. Keraguan mereka didasari karena ketidaksesuaian pengetahuan mereka dengan informasi yang didapat melalui media internet. Selain itu, masih terdapat banyak informasi yang mereka anggap sudah tidak lagi sesuai dengan situasi mereka. Akurasi sangat terkait erat dengan up date informasi yang diberikan dan kehandalan informasi. Bagi informasi yang sifatnya baru, sebagian besar petani mungkin bisa diterima sebagai informasi yang akurat, tetapi bagi informasi yang sifatnya tidak up to date mereka menganggap sudah tidak akurat di lapangan. Mereka menilai bahwa informasi yang mempunyai nilai akurat tinggi adalah informasi terkait dengan informasi kebijakan-kebijakan pemerintah. Selain karena melalui situs resmi, informasi konsisten (handal), mereka menganggap bahwa informasi ini memang ditujukan kepada seluruh warga masyarakat. Dari segi keaktualan, hanya 40.3 persen petani yang menilai bahwa informasi bersifat up to date, mereka menganggap masih banyak informasi yang sifatnya sudah kadaluarsa terutama terkait dengan pengelolaan teknik budidaya dari sumber dalam negeri. Tidak sedikit dari mereka (petani sayuran) Jawa Barat justru mencari informasi yang sifatnya mempunyai keinovatifan tinggi. Mereka beranggapan bahwa produk atau teknik budidaya terbaru membuat satu hal baru yang menguntungkan usahanya.

Bagi sebagian petani (32.5\%) menganggap bahwa beberapa informasi telah mereka jadikan panduan dalam melaksanakan kegiatan usahataninya (kehandalan informasi). Mereka yang menjadikan informasi sebagai panduan usahataninya, merasa cukup percaya informasi yang mereka dapatkan. Beberapa diantara mereka (67.5\%) menindaklanjuti informasi (setelah melalui proses kesadaran dan ketertarikan informasi) menghubungi sumber informasi langsung (biasanya penyuluh lapangan) guna mengetahui lebih jauh tentang informasi tersebut. Artinya, kekuatan informasi yang berasal dari media internet sebagian besar hanya sampai pada tahap awareness dan interest. Setelah dirasakan cukup, mereka mempraktekan informasi tersebut, bahkan terkadang komunikasi berlanjut baik melalui telepon genggam atau satu bentuk pertemuan antara sumber informasi dengan sumber informasi. Mereka menilai informasi kebijakan pemerintah, informasi input produksi, informasi pemasaran dan beberapa informasi teknik pengelolaan budidaya yang mereka anggap baik mempunyai nilai yang bisa diandalkan. Bahkan 27.6 persen diantaranya menggunakan informasi harga input, harga pasar sebagai pegangan mereka menetapkan harga dasar. Dari segi kelengkapan informasi, sebagian besar petani menganggap informasi dirasakan belum lengkap. Artinya, informasi masih belum dapat memuaskan kebutuhan informasi mereka. Sebagian petani (44.9\%) menilai masih rendah dan sebagian lain (53.5\%) menilai cukup lengkap. Informasi yang sifatnya lengkap adalah informasi mengenai input produksi, alamat pemasaran dan informasi kebijakan. 37.5 persen petani yang menilai masih kurang lengkap kembali menanyakan kepada para petugas di lapangan.

Meskipun masih terdapat beberapa kendala terkait kualitas informasi sehingga menjadikan sulitnya informasi utamanya inovasi untuk diadopsi, informasi melalui internet sebenarnya dapat menyediakan kesempatan yang lebih besar untuk mencapai suatu tingkatan tertentu yang lebih baik bagi petani secara keseluruhan apabila didukung oleh peran sumber informasi yang memanfaatkan media informasi sebagai media penyebaran inovasi. Hal ini ditunjukkan ketika beberapa lembaga penelitian dan pengembangan menyampaikan 
studi kasus yang mendeskripsikan bagaimana internet telah dimanfaatkan oleh petani dan stakeholders usahawan pelaku bidang pertanian sehingga memperoleh peluang yang lebih besar untuk memajukan kegiatan usahataninya. Keberhasilan pemanfaatan informasi melalui internet oleh petani sayuran di Indonesia dalam memajukan usahataninya ditunjukkan oleh beberapa kelompoktani yang telah memanfaatkan internet untuk akses informasi dan promosi hasil produksinya dengan menggunakan fasilitas yang disediakan Community Training and Learning Centre (CTLC) di Pancasari (Bali) dan Pabelan (Salatiga) yang dibentuk Microsoft bekerja sama dengan lembaga nonprofit di bawah Program Unlimited Potential. Dijumpai juga dilapangan, banyak petani yang tergabung dalam kelompoktani, mengenal teknologi budidaya terbarukan melalui internet. Beberapa dari mereka, mengirimkan profil produksi di internet, permintaan terhadap produk pertanian yang diusahakan terus berdatangan. Seperti dituturkan Sigit et al. (2006), promosi melalui internet dapat memutus hubungan petani dengan tengkulak yang sering memberikan harga jauh di bawah harga pasar.

\section{Kapabilitas Petani Mengelola Inovasi}

Era globalisasi menuntut seluruh organisasi/ lembaga untuk mampu menerima muatan-muatan global untuk diserap ke dalam organisasinya dan sekaligus mampumengglobalkanyanglokal sehingga dapat diterima oleh masyarakat seluruh dunia. Semuanya dilakukan melalui media jaringan terkoneksi internet. Internet telah memaksa desakan produk yang inovatif dalam dunia bisnis dan membuka lebar kebebasan konsumen untuk dapat memilih produk-produk yang dapat memuaskan mereka, termasuk di dalamnya produk hasil pertanian. Dengan demikian, agar dapat mencapai keberhasilan inovasi, maka seorang individu (petani) perlu terlebih dahulu memahami kapabilitas inovasi yang dimilikinya. Apakah petani sudah berkapabilitas? kapabilitas petani mengelola inovasi dapat diketahui melalui nilai kapabilitas inovasi yang dimilikinya. Dengan pemahaman pentingnya kapabilitas petani mengelola inovasi, dapat membantu individu petani untuk menerapkan inovasi dengan baik. Sebab keberhasilan individu dalam adopsi inovasi tidak terjadi begitu saja, namun terdapat faktor-faktor yang mempengaruhi kesuksesan dalam menerapkan inovasi. Indikator kapabilitas petani mengelola inovasi diukur dengan lima indikator: (1) kemampuan beradaptasi dengan inovasi; (2) kemampuan menyaring inovasi; (3) kemampuan komitmen terhadap inovasi; (4) kemampuan melaksanakan inovasi; dan (5) kemampuan mengelola sumberdaya yang ada.

Variabel kapabilitas petani mengelola inovasi diukur dengan menggunakan 58 butir pernyataan yang relevan dengan dimensi fungsi aktivitas inovasi. Berikut ini diuraikan gambaran tanggapan responden sesuai dengan variabel yang dimaksud. Kesimpulan mendasar yang dapat diambil dari angka persentase Tabel 2 adalah bahwa dalam melaksanakan aktivitas inovasi, sebagai perencana sekaligus pelaksana usahatani maka aktivitas inovasi yang meliputi kemampuan beradaptasi dengan inovasi, kemampuan menyaring inovasi, kemampuan komitmen terhadap inovasi, kemampuan mengelola sumberdaya yang ada dan kemampuan melaksanakan inovasi merupakan hal yang utama yang harus ditingkatkan. Hal ini dilihat dari ukuran indikator "rendah" para responden, ini menunjukkan pengetahuan tentang inovasi rendah; kurang berani mengambil resiko; keterbatasan modal; keterbatasan sumberdaya pendukung inovasi; dan minimnya bimbingan pelatihan keterampilan inovasi. Sebagian besar responden tidak serta merta menerapkan kaidah inovasi dalam usahataninya.

Tabel 2. Jumlah dan persentase penilaian petani terhadap indikator kapabilitas petani mengelola inovasi, Tahun 2015

\begin{tabular}{|c|c|c|c|c|c|c|c|c|c|c|c|}
\hline \multirow{3}{*}{ No. } & \multirow{3}{*}{$\begin{array}{c}\text { Indikator Kapabilitas petani } \\
\text { mengelola inovasi }\end{array}$} & \multicolumn{8}{|c|}{ Rekapitulasi Skor Jawaban Responden } & \multirow{2}{*}{\multicolumn{2}{|c|}{ Total }} \\
\hline & & \multicolumn{2}{|c|}{ Sangat rendah } & \multicolumn{2}{|c|}{ Rendah } & \multicolumn{2}{|c|}{ Sedang } & \multicolumn{2}{|c|}{ Tinggi } & & \\
\hline & & $\mathrm{n}$ & $\%$ & $\mathrm{n}$ & $\%$ & $\mathrm{n}$ & $\%$ & $\mathrm{n}$ & $\%$ & $\mathrm{~N}$ & $\%$ \\
\hline 1. & $\begin{array}{l}\text { Kemampuan menyesuaikan dengan } \\
\text { inovasi }\end{array}$ & 15 & 6,0 & 137 & 56,5 & 67 & 27,7 & 24 & 9,9 & 243 & 100,0 \\
\hline 2. & Kemampuan menyaring inovasi & 12 & 4,7 & 135 & 55,6 & 58 & 23,8 & 39 & 15,9 & 243 & 100,0 \\
\hline 3. & $\begin{array}{l}\text { Kemampuan mengelola sumberdaya } \\
\text { yang ada }\end{array}$ & 17 & 6,9 & 137 & 56,4 & 61 & 24,9 & 28 & 11,7 & 243 & 100,0 \\
\hline 4. & $\begin{array}{l}\text { Kemampuan komitmen terhadap } \\
\text { inovasi }\end{array}$ & 14 & 5,7 & 132 & 54,4 & 67 & 27,6 & 30 & 12,3 & 243 & 100,0 \\
\hline \multirow[t]{3}{*}{5.} & Kemampuan melaksanakan inovasi & 14 & 5,6 & 130 & 53,3 & 65 & 26,9 & 35 & 14,2 & 243 & 100,0 \\
\hline & Akumulasi & 70 & & 671 & & 318 & & 155 & & 1.215 & \\
\hline & Jumlah skor & & 70 & & 1.342 & & 954 & & 622 & & 2.988 \\
\hline
\end{tabular}


Jumlah skor tanggapan responden atas butir pernyataan dalam lima dimensi pada variable kapabilitas petani mengelola inovasi diperoleh nilai sebesar 2.988 dengan bobot skor tertinggi adalah 4 dan bobot terendah 1. Jika diklasifikasikan menjadi empat tingkatan maka rentang skor antar tingkatan dapat dihitung dengan cara menghitung nilai skor minimum: 1 x 243 x $5=1.215$; nilai skor maksimum: 4 × 243 x $5=4.860$. Didapatkan Range: $4.860-1.215=3.645$ sehingga jenjang range: $3.645: 4=911$ (pembulatan).

Dari hasil perhitungan Tabel 2, dibuat skala penilaian dengan kategori sangat rendah skor (1.2152.126), rendah (2.127-3.038), sedang (3.039-3.949) dan tinggi (3.950-4.860). Interval kategori untuk jumlah total skor tanggapan responden dalam lima dimensi variabel kapabilitas mengelola inovasi dengan nilai 2.988. Berdasarkan interval kategori tersebut dapat disimpulkan bahwa tanggapan responden mengenai pernyataan kapabilitas petani mengelola inovasi, secara umum termasuk dalam kategori rendah, hal tersebut menunjukkan bahwa kapabilitas petani sayuran Jawa Barat masih dapat dan perlu ditingkatkan melalui berbagai upaya perbaikan. Salah satu diantaranya adalah melalui perbaikan informasi melalui media internet. Guna mengetahui seberapa besar pengaruh jika perbaikan kualitas informasi dilakukan maka dianalisis secara regresi linear.

\section{Pengaruh Kualitas Informasi terhadap Kapabilitas Petani Mengelola Inovasi}

Dari hasil perhitungan model regresi dapat dilihat bahwa variabel kapabilitas petani mengelola inovasi (Y) dijelaskan oleh variabel kualitas informasi (X) sebesar koefisien determinasi $(\mathrm{R} 2)=72.5$ persen dan sisanya dijelaskan oleh variabel lain sebesar 27.5 persen. Keberartian secara simultan variabel-variabel bebas dapat dilihat dari hasil Uji-F. Dari output perhitungan yang dihasilkan pada perhitungan regresi linier berganda didapat $\mathrm{F}_{\text {hitung }}=5.26$ dengan nilai $\mathrm{F}_{\text {tabel }} 0.14$ pada signifikansi penelitian 0.05 . Keputusannya $\mathrm{F}_{\text {hitung }}$ $>\mathrm{F}_{\text {tabel }}$ berarti benar bahwa, kualitas informasi dengan karakteristik relevan, kepahaman, akurasi, kehandalan, keaktualan, kelengkapan dan ketepatwaktuan, secara simultan berpengaruh terhadap kapabilitas petani mengelola inovasi.

Dengan demikian, perhatian terhadap kualitas informasi ini menjadi penting, mengingat informasi ini merupakan basis pengambilan keputusan. Dapat dibayangkan kalau kualitas informasi tersebut tidak mempunyai kualitas tinggi, keputusan yang diambil berpotensi besar menjadi keliru dan merugikan petani, dengan demikian kinerja usahatani dapat dikatakan kurang baik. Hasil penelitian ini menunjukan bahwa pada umumnya terdapat pengaruh karakteristik informasi terhadap kapabilitas petani mengelola inovasi. Semakin berkualitas informasi yang diperoleh petani, kemudian informasi tersebut dijadikan dasar pengelolaan usahatani, maka dapat meningkatkan kemampuan inovasi untuk meraih kesuksesan usaha. Informasi yang dikumpulkan dan dikelola dengan baik dapat menghasilkan pengetahuan dan dapat memberikan manfaat yang sangat besar bagi yang melakukannya. Untuk dapat dimanfaatkan, informasi harus dialirkan dari sumbersumber informasi kepada para penggunanya dengan ketentuan memenuhi prasyarat di atas. Adanya pemasok dan pengguna yang berbeda lokasi, berbeda kemampuan, berbeda kondisi sosial-ekonomi-budaya menyebabkan perlunya memperhatikan penyesuaian situasi dan kondisi dari pengirim, pengguna dan kandungan informasi.

Hasil uji regresi memberi arti bahwa keputusan yang didasarkan pada informasi yang berkualitas, berdampak kepada terciptanya inovasi ditingkat petani. Inovasi diartikan sebagai salah satu faktor penting dalam usahatani khususnya usahatani sayuran dataran tinggi, karena dengan adanya inovasi diharapkan dapat meningkatkan usahataninya. Gambaran kapabilitas petani mengelola inovasi juga merupakan salah satu faktor yang dapat dipakai tolak ukur kinerja petani. Kapabilitas petani mengelola inovasi menunjukkan perilaku petani dalam menjalankan aktivitas bisnisnya melalui suatu inovasi, yang tentu selalu berkenaan dengan pengambilan keputusan. Hal ini berdasarkan pandangan bahwa kinerja usahatani yang dilakukan petani baik jika ia berkemampuan menjalankan fungsi atau aktivitas bisnisnya tersebut dengan mengelola inovasi, dimana kemampuan tersebut dipengaruhi oleh informasi yang berkualitas yang diperoleh dari sistem informasi yang terarah dan terintegrasi dengan baik, guna mendukung proses pengambilan keputusan usahatani.

\section{SIMPULAN}

Tingkat kapabilitas petani mengelola inovasi masih rendah dan persepsi terhadap kualitas informasi dinyatakan sedang. Penilaian petani terhadap informasi yang berkualitas secara berurutan adalah: (1) informasi harga; (2) informasi berupa hasil penelitian; (3) informasi pemasaran; dan (4) informasi kebijakan pertanian. Karakteristik kualitas informasi yang terdiri atas relevansi, kepahaman, akurasi, kehandalan, keaktualan, kelengkapan dan ketepatwaktuan, secara serempak berpengaruh terhadap kapabilitas petani mengelola inovasi.

\section{DAFTAR PUSTAKA}

Baser H and P Morgan. 2008. Capacity, Change and Performance: Study Report. European Centre for Development Policy Management.

DeJong JPJ and Kemp R. 2003. Determinants Of CoWorkers's Innovative Behaviour: An Investigation Into Knowledge Intensive Service. International 
Journal of Innovation 4 Management. 7(2):189212 (Juni 2003). Diakses melalui EBSCO Publisher 22 Maret 2005.

DeLone WH dan McLean ER. 1992. Information Systems Success. The Quest for the Dependent Variable. Information Systems Research. (3):6095.

Jogiyanto. 2007. Sistem Informasi Keperilakuan. Andi Offset. Yogyakarta.

Laudon KC dan JP Laudon. 2007. Sistem Informasi Manajemen. Edisi ke 10. Terjemahan Chriswan Sungkono dan Machmudin Eka P. Salemba Empat. Jakarta.

Maureen. 2009. How Can ICTs Promote Sustainable Agriculture?. http://www.citizenjournalismafrica. org/blog/persen5Buser persen5D/05. Aug 2011. 1856. [Diunduh pada tanggal 24 Oktober 2014].

McLeod R dan George S. 2007. Management Information System, 10th. New Jersey: Inc,. Upper Saddle River.
Mulyandari RSH dan E Eko A. 2005. Teknik Implementasi Pengembangan Sumber Informasi Pertanian Nasional dan P4MI. Informatika Pertanian. 14.

O’Brien JA. 2005. Pengantar Sistem Informasi Perseptif Bisnis dan Manajerial. Salemba.

Sangkala. 2007. Knowledge Management: Suatu Pengantar Memahami Bagaimana Organisasi Mengelola Pengetahuan Sehingga Menjadi Organisasi yang Unggul. Rajawali Press. Jakarta.

Sarwono SW. 2005. Manusia Indonesia: Mentalitas Prapertanian di Era Informasi "Cyber" dalam Bunga Rampai "Revitalisasi Pertanian dan Dialog Peradaban”. Jakarta (ID): Kompas.

Sigit I, Mukhlison SW, dan A Wibisono. 2006. [Laporan Khusus, Gatra. (38). Beredar Kamis, 3 Agustus 2006].

Umar N. 1999. 225. Argumen Kesetaraan Jender: Perspektif Al-Qur'an. Paramadina. Cet. I. Jakarta.

Vivek A. 2011. Cyber Extension: A Convergence Of ICT and Agrikultural Development. Global Media Jurnal. Indian Edittion. Winter Issue/December 2011. 2(2). 